\title{
Identification of Estrogen-Responsive Genes in Neuroblastoma SK-ER3 Cells
}

\author{
M. Garnier, ${ }^{1,2}$ D. Di Lorenzo, ${ }^{2}$ A. Albertini, ${ }^{2}$ and A. Maggi ${ }^{1}$ \\ 1/nstitute of Pharmacological Sciences, University of Milan, I-20133 Milan, Italy, and 2Laboratory of Hormonology and \\ Toxicology, Civic Hospital Brescia, and Institute of Chemistry, School of Medicine, University of Brescia, I-25123 \\ Brescia, Italy
}

To evaluate the role of estrogen receptor in the differentiation of cells of neural origin, we developed a molecular approach aimed at the identification of estrogen target genes by mRNA differential display PCR (ddPCR) in human neuroblastoma SKER3 cells. More than 3000 RNAs were examined, a few of which displayed a differential regulation pattern in response to $17 \beta$-estradiol $\left(E_{2}\right)$. Sequence analysis of three differentially amplified ddPCR products showed homology with the growthassociated nuclear protein prothymosin- $\alpha$ (PTMA), the Bcl2interacting protein Nip2, and one mRNA previously described by others in fetal human brain. Two ddPCR products, referred to as P4 and P10, corresponded to new DNA sequences. Northern analysis confirmed that estrogen treatment of SK-ER3 cells resulted in the upregulation and downregulation of expression of these messages. In particular, PTMA was found to accumulate at both 1 and $17 \mathrm{hr}$ after $\mathrm{E}_{2}$ treatment, whereas P10 product accumulated only at $1 \mathrm{hr}$. Conversely, P4, Nip2, and the fetal brain-related mRNAs were significantly decreased by the treatment. Further time course analysis of PTMA and Nip2 mRNAs levels indicated that the hormone exerted a marked biphasic regulatory effect on expression of both messages during the course of cell differentiation. In the present study we report for the first time the identification of a panel of estrogen target genes in neural cells that provide new insights in the molecular mechanism of action of $E_{2}$ in cells of neural origin.

Key words: differential display PCR; gene expression; estrogen; growth; differentiation; apoptosis; neuroblastoma; neural cells; Nip2; prothymosin- $\alpha$; interleukin-2 $\beta$-converting enzyme/ Ced-3 proteases
Estrogens are important endocrine modulators exerting powerful pleiotrophic effects in mammals by acting on several organs. Among these, the brain is certainly a relevant target (McEwen et al., 1979; MacLusky and Naftolin, 1981). For quite a long time, $17 \beta$-estradiol $\left(\mathrm{E}_{2}\right)$ has been known as the key element for the differentiation of a number of sexually dimorphic brain areas and for the modulation of sex-related brain activities and behaviors in adult mammals (Parsons et al., 1980; McEwen, 1983; ToranAllerand, 1984). More recently, however, it has been shown that estrogens can also influence extrahypothalamic brain functions such as learning and memory, cognition, and motivation (Tallal, 1991; Luine, 1994; Sherwin, 1994) and can act as a protective factor in the manifestation of affective and neurodegenerative disorders (Maggi and Perez, 1985; Tang et al., 1996). This extrahypothalamic activity of estrogens was further supported by the finding of estrogen receptors and estrogen-regulated genes in limbic areas of adult mammalian brain (Maggi et al., 1989; Bettini and Maggi, 1992; Toran-Allerand et al., 1992).

Estrogens regulate gene transcription by binding through their cognate receptors to specific regulatory DNA sequences within

Received March 10, 1997; accepted April 1, 1997.

This work was supported by Contract N. ERBCHBGCT930311 established between the European Economic Community and the University of Brescia, Italy (M.G.), and grants from the Italian National Council of Research (Consiglio Nazionale delle Ricerche, Progetto strategic oligonucleotidi antisenso Grant PCT/EP92/ 01745) (A.M.) and Italian Association for Cancer Research (A.M.). We particularly thank M. Rebecchi for her technical assistance during this work and are grateful to S. Santagati and E. Vegeto for their helpful discussions and comments on this manuscript.

Correspondence should be addressed to Adriana Maggi, Institute of Pharmacological Sciences, University of Milan, Via Balzaretti 9, I-20133 Milan, Italy.

Copyright (C) 1997 Society for Neuroscience 0270-6474/97/174591-09\$05.00/0 the promoter of target genes (Evans, 1988; Kumar and Chambon, 1988; Klein-Hitpass et al., 1989). Conceptually, the same molecular mechanisms should be used by estrogens in neural cells. Consistent with this idea, in vivo and in vitro studies in neural cells or tissues reported that estrogens can modulate the content of transcripts coding for specific proteins, including synapsisassociated proteins (Shughrue and Dorsa, 1993), neurotrophins (Toran-Allerand, 1996), neurotransmitter receptors (Summer and Fink, 1993), proto-oncogenes (Pahlman et al., 1990; Santagati et al., 1995), and mitochondrial enzymes (Bettini and Maggi, 1992).

Rapidly accumulating data point to the multiplicity of effects of $\mathrm{E}_{2}$ in neural cells. However, a systematic study aimed at identifying the intracellular events triggered by the hormone is still missing. In the past, we attempted the identification of estrogen target genes in brain tissue by the use of subtractive libraries (Bettini and Maggi, 1992). However, this approach did not prove suitable to study a tissue as complex as the brain. This prompted us to develop a neuroblastoma cell line, named SK-ER3, expressing the estrogen receptor (ER), which could be used as a cell model to study the molecular effects of $E_{2}$ in cells of neural origin. The data accumulated so far prove that $\mathrm{E}_{2}$ can induce these cells to cease proliferation and to accumulate in the $G_{0}$ phase of the cell cycle, acquiring the phenotype of a mature dopaminergic neuron (Agrati et al., 1997). We also proved that several of the activities attributed to $\mathrm{E}_{2}$ in vivo can be reproduced in our model, i.e., induction of the synthesis of specific proteins, including c-Fos, synaptophysin, and tau, or modulation of neurite growth (Ma et al., 1993; Santagati et al., 1995). We therefore believe that SKER3 cells represent a unique system for the study of $E_{2}$ action in neural cells. 
Using this cellular model and the differential display PCR (ddPCR) method (Liang and Pardee, 1992; Douglass et al., 1995), we undertook the identification of estrogen-regulated genes. Our results show that $E_{2}$ regulates the expression of genes associated with cell growth, differentiation, and survival. These data might provide new molecular basis to explain the protective effects of estrogens in the development of neurodegenerative disorders.

\section{MATERIALS AND METHODS}

Materials. RPMI-1640 was from Sigma (Milan, Italy). Fetal bovine serum was from Imperial (Unipath, Milan, Italy); trypsin was from Gibco (Paisley, UK); and tissue culture plastic ware was from Corning (New York, NY). 17 $\beta$-Estradiol from Sigma (St. Louis, MO) was stored at $-20^{\circ} \mathrm{C}$ at a concentration of $10 \mathrm{mM}$ in ethanol. $\alpha-\left[{ }^{35} \mathrm{~S}\right] \mathrm{dATP}(>1000$ $\mathrm{Ci} / \mathrm{mmol}$ ) was purchased from DuPont (Milan, Italy). All electrophoresis and Northern analysis reagents were from Bio-Rad (Milan, Italy) and Boehringer Mannheim (Milan, Italy), respectively.

Cell culture and RNA extraction. SK-ER3 cells were routinely grown in RPMI-1640 medium without phenol red, supplemented with $10 \%$ charcoal-stripped fetal bovine serum. For all experiments, cells were used at passage between 36th and 40th to minimize cell culture-induced modifications. Cells were split at subconfluency by trypsinization $(0.5 \mathrm{gm} / 1$ trypsin and $0.2 \mathrm{gm} / 1$ EDTA) and dissociation in RPMI-1640 medium. For the ddPCR and Northern experiments, cells were seeded in $35 \mathrm{~mm}$ tissue culture dishes at a density of $5 \times 10^{5}$ per dish and grown for $2 \mathrm{~d}$ in the medium described above. If not otherwise specified, vehicle (ethanol, $0.001 \%)$ or $\mathrm{E}_{2}(5 \mathrm{nM})$ was then added to fresh medium, and cells were further grown for 1 or $17 \mathrm{hr}$.

Total RNA was obtained using a single-step RNA isolation method by guanidine thiocyanate-urea-phenol-chloroform extraction (Chomczynski and Sacchi, 1987). Briefly, cells were homogenized in Bio/RNA-XCell reagent (Bio/Gene, Kimbolton Cambs, UK), and RNA was extracted and further purified with an RNA-binding resin as recommended by the manufacturer (Bio/Gene). RNAs were stored at $-20^{\circ} \mathrm{C}$ at a concentration of $1 \mu \mathrm{g} / \mu \mathrm{l}$ in sterile water and subsequently used for ddPCR and Northern analysis.

Differential display PCR. Total RNA $(5 \mu \mathrm{g})$ from control and treated cells was first digested with $10 \mathrm{U}$ of DNase I (GeneHunter, Brookline, MA) for $30 \mathrm{~min}$ at $37^{\circ} \mathrm{C}$ to remove any trace of DNA contaminant. After phenol-chloroform extraction and ethanol precipitation, RNA was diluted to a concentration of $0.1 \mu \mathrm{g} / \mu \mathrm{l}$ in sterile water. The ddPCR experiments were performed essentially as originally described (Liang and Pardee, 1992) using the RNAimage mRNA differential display system (GeneHunter). Three different reverse transcription (RT) reactions were carried out on $0.2 \mu \mathrm{g}$ of DNA-free RNA using a $1 \mathrm{~b}$ anchor oligo-dT primer, $\mathrm{H}-\mathrm{T}_{11} \mathrm{~A}, \mathrm{H}-\mathrm{T}_{11} \mathrm{G}, \mathrm{H}-\mathrm{T}_{11} \mathrm{C}$ (where $\mathrm{H}=\mathrm{AAGCTT}$ ) to generate different fractions of cDNAs. Twenty microliter PCR reactions were then performed on 1:10 aliquots of the RT mixtures using the same anchor oligo-dT primer ( $3^{\prime}$-primer) and a 13 -mer primer that contained a $7 \mathrm{~b}$ arbitrary sequence $\left(5^{\prime}\right.$-primer). Twelve different $5^{\prime}$-primers were tested and referred to as H-AP1-H-AP12. For each primer combination $(0.2 \mu \mathrm{M}$ each), a 40 cycle PCR was run in the presence of $2 \mu \mathrm{M} \mathrm{dNTP,} 10 \mu \mathrm{Ci}$ $\left[\alpha^{35}\right.$ S $]$ dATP, and $1 \mathrm{U}$ of AmpliTaq DNA polymerase (Perkin-Elmer, Milan, Italy) in a Hybaid thermal cycler (Celbio, Milan, Italy) with the following thermal profile: 1 min denaturation at $94^{\circ} \mathrm{C}, 2$ min annealing at $40^{\circ} \mathrm{C}$, and $1 \mathrm{~min}$ extension at $72^{\circ} \mathrm{C}$, followed by a $5 \mathrm{~min}$ final extension step at $72^{\circ} \mathrm{C}$. The amplification products were then separated by electrophoresis at $1800 \mathrm{~V}$ for $4-5 \mathrm{hr}$ on a $6 \%$ polyacrylamide-urea gel and identified by autoradiography using $\beta$-max films (Amersham, Buckingamshire, UK). The PCR products showing amplification differences between control and $\mathrm{E}_{2}$-treated cells were excised from the gel, eluted in sterile distilled water, and reamplified by PCR using the same primer combination that generated them. The PCR parameters and protocol were unchanged, except that the dNTP concentration was brought to $20 \mu \mathrm{M}$, and reaction were performed in $40 \mu \mathrm{l}$. The reamplified PCR products were then electrophoresed on a $1.5 \%$ agarose gel for size estimation and further screening analysis.

Sequence analysis of the ddPCR products. ddPCR products were directly sequenced after PCR reamplification using a cycling sequencing protocol (Innis et al., 1988). Briefly, the agarose band containing the reamplified ddPCR DNA product was excised from the gel, and the DNA was recovered using a Micropure/Microcon-50 assembly device (Amicon, Beverly, MA). Aliquots (1:10) of the purified DNA were used as tem- plates for cycling sequencing using the AmpliCycle sequencing kit (Roche Molecular Systems, Branchburg, NJ). The protocol was essentially as recommended by the manufacturer, except that the primer concentration was increased to $1 \mu \mathrm{M}$. Each fragment was sequenced in both directions using either of the original ddPCR primers. The thermal cycling profile was the same as for the ddPCR reactions. The sequencing products were separated by electrophoresis on a $6 \%$ polyacrylamide-urea gel and identified by autoradiography. A computer search analysis was performed on each sequence to look for homology using EMBL and GenBank DNA databases and the Fasta or Blast algorithms (Altschul et al., 1990).

Nonradioactive Northern blot analysis. Ten micrograms $\mu \mathrm{g}$ of total RNA were isolated as described above, electrophoresed on a $1 \%$ agaroseformamide gel (Sambrook et al., 1989), and transferred to positively charged $\mathrm{N}^{+}$nylon membrane (Amersham). Nonradioactive probes were synthesized by PCR from purified ddPCR products (1:1000 final dilution) in a $50 \mu \mathrm{l}$ reaction volume in the presence of $70 \mu \mathrm{M}$ digoxigenin (DIG)labeled deoxyuridine triphosphate (Boehringer Mannheim), $130 \mathrm{M}$ dTTP, $200 \mu \mathrm{M}$ concentrations of deoxynucleotide triphosphates, and the corresponding ddPCR primers ( 5 pmol each). The DIG probes were separated from free nucleotides by electrophoresis on an agarose gel and further recovered from gel using Micropure/Microcon-50 units (Amicon). DIGlabeled probes were used for hybridization to membrane-transferred RNAs according to conventional methods (Sambrook et al., 1989) with a typical hybridization reaction at $42^{\circ} \mathrm{C}$ for $36 \mathrm{hr}$ in $50 \%$ formamidecontaining hybridization buffer. Membranes were then washed with $5 \times$ SSC solution two times for $30 \mathrm{~min}, 0.1 \times$ SSC $0.1 \%$ SDS for $30 \mathrm{~min}$, and $0.01 \times \mathrm{SSC} / 0.1 \%$ SDS two times for $15 \mathrm{~min}$. The hybridized probes were immunodetected with an anti-DIG-AP and Fab fragments and were visualized with the chemiluminescence substrate disodium 3-(4methoxyspiro $\left\{1,2\right.$-dioxetane-3,2'-(5'-chloro)tricyclo[3.3.1.1 $\left.1^{3,7}\right]$ decan $\}-4$ yl)phenyl phosphate reagent using the DIG luminescent detection kit (Boehringer Mannheim). Membranes were further exposed to MP hyperfilms (Amersham) for $30 \mathrm{~min}-2 \mathrm{hr}$, and relative band intensities were measured by densitometric analysis of autoradiographs. Results were analyzed after different exposure durations to ensure that all the bands compared were in the linearity range of detection. Differences in the amounts of RNA loaded were normalized with respect to the 18 and 28 $\mathrm{S}$ ribosomal RNAs stained by ethidium bromide.

PCR amplification using specific oligonucleotides. For specific amplification and sequencing of prothymosin- $\alpha$ (PTMA) DNA, the following primers were used: 5'-TCATCGGATCACCGGCG-3' (forward) and 5'TCCTCTTCTTCGTCTAC-3' (reverse). PCR amplifications were performed on cDNAs obtained with $\mathrm{H}$-dT11A oligo-dT primer from $\mathrm{E}_{2}$ treated cell RNAs as described above. After 32 cycle amplification, the PCR product was diluted to 1:100 and sequenced in both directions by cycling sequencing PCR using either a reverse or forward primer. The PCR amplification profiles used for generating the PTMA fragment and for sequencing were identical $\left(1 \mathrm{~min}\right.$ at $94^{\circ} \mathrm{C}, 30 \mathrm{sec}$ at $56^{\circ} \mathrm{C}$, and $30 \mathrm{sec}$ at $72^{\circ} \mathrm{C}$ ). Sequencing products were then separated by electrophoresis on a $6 \%$ polyacrylamide-urea gel and identified by autoradiography.

\section{RESULTS}

\section{Differential display of $\mathrm{E}_{\mathbf{2}}$-regulated mRNAs}

In the present study, we focused on the early genomic events induced by $E_{2}$ in SK-ER3 cells. On the basis of previous studies showing that the growth arrest of these cells by $E_{2}$ requires at least $17 \mathrm{hr}$ of continuous presence of the hormone (Ma et al., 1993), total RNA was prepared from subconfluent SK-ER3 cells, control or treated with $1 \mathrm{~nm} \mathrm{E}_{2}$ for 1 or $17 \mathrm{hr}$. The RNA populations were reverse-transcribed using three different anchor oligo-dT 3'primers. Because the number of products amplified by a given combination of primers and exhibiting a differential pattern of amplification was usually rather small, a good number of the 5 '-primers needed to be used. In this study, 36 different primer combinations were used. In preliminary experiments, each primer set was tested in single PCR reactions on total RNA preparations from both control and treated cells. The amplified PCR products generated from each reaction were compared side by side after electrophoresis on urea-acrylamide sequencing gels. An average of 150-200 PCR products could be visualized on each electrophoretic lane with an average of two to five products showing a 


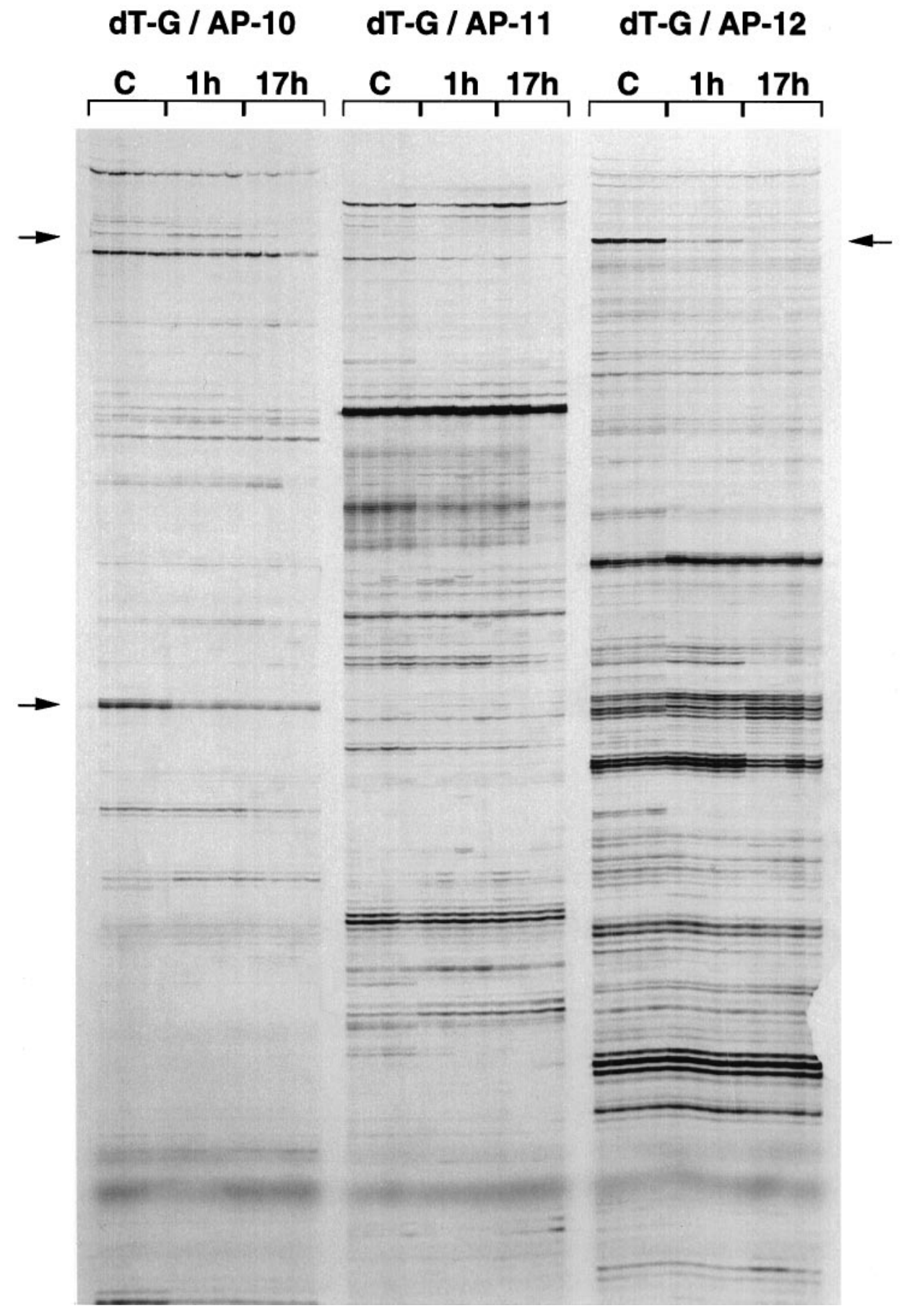

Figure 1. Fingerprints of RNAs extracted from SK-ER3 neuroblastoma cells and screened by differential display PCR. Total RNAs from control $(C)$ and $\mathrm{E}_{2}$-treated $(1 \mathrm{~h}$ and $17 \mathrm{~h}$ ) cells were reverse-transcribed in duplicate reactions using a $1 \mathrm{~b}$ anchor oligo-dT primer $\left(\mathrm{dT}_{11}-\mathrm{G}\right)$. PCR reactions were performed in duplicate on each cDNA mix using various combinations of $\mathrm{dT}_{11}-\mathrm{G}$ and arbitrary forward primers (AP-10, AP-11, and AP-12) in the presence of $10 \mu \mathrm{Ci}$ of $\alpha-\left[{ }^{35} \mathrm{~S}\right] \mathrm{dATP}$. The amplified products were then separated on a $6 \%$ acrylamide-urea gel and visualized by autoradiography. Arrows point to differentially amplified products in control versus $\mathrm{E}_{2}$ treated cells identified within one set of ddPCR reactions. differential amplification pattern. To verify the reproducibility of the amplification patterns, the reactions showing differentially amplified products were repeated performing both RT and ddPCR reactions in duplicates. Each primer combination generated a distinct pattern of amplification. In particular, the same 5 '-primer combined with each specific oligo-dT 3'-primer produced a unique pattern of amplification, indicating that the anchor primers used for the RT reactions had generated distinct subpopulations of cDNAs. Fig. 1 shows a representative autoradiograph obtained from one experiment in which three different sets of ddPCR reactions were performed at the same time on control (lanes $C$ ) and $\mathrm{E}_{2}$-treated cells (lanes $1 \mathrm{~h}$ and $17 \mathrm{~h}$ ) using three different primer combinations (dT-G/AP-10, dT-G/AP-11, and dT-G/AP12). The analysis of the amplification patterns generated by one set of primers showed that the intensity of the majority of the bands did not change with the treatment. However, a limited number of bands exhibited reproducible variations; the arrows point to few of them. In total, 13 bands with sizes larger than 150 bp showing an $E_{2}$-regulated amplification profile were excised from gels to be further analyzed. Eleven products were successfully reamplified with a single round of 40 cycle PCR and partially sequenced (Table 1 ). The characterization and the extent of amplification of these products are presented in Table 2. The search for possible homologies, using GenBank and EMBL databases, did not score a good degree of homology for seven of the ddPCR products selected, suggesting that they may not be related 


\begin{tabular}{|c|c|c|}
\hline Product & Sequence $^{a}$ & Accession number \\
\hline \multirow[t]{2}{*}{$\mathrm{P} 1$} & caacacccactacctaaaaaataccaaacatatgactgaactccncacacccaataggaccaatctatcaccc & \\
\hline & tatagacagatcta & U74657 \\
\hline \multirow[t]{2}{*}{$\mathrm{P} 2$} & tcctgatgttgtagcgggacttgttggttcatcttagttaatgtgccaaggtgatctaagttgcctaccttga & \\
\hline & attttttttaaatatatttgatgacataaaggcc & U74656 \\
\hline \multirow[t]{2}{*}{$\mathrm{P} 3$} & ggtagacgaagaagaggaagaaggtggggaggaagaggaggaggaagaagaaggtgatggtgaggaagaggat & \\
\hline & ggagatgaagatgaggaagctgagtcagctacgggcaagcgggcagctgaagatgatgaggatgacgatgtcgataccaagaagcagaaga & U74658 \\
\hline \multirow[t]{2}{*}{$\mathrm{P} 4$} & gatgcatataattcatatcttgaagattatgctttgattttaaaatattttgcttcaaataagggattcgaca & \\
\hline & gtagtgaagatgcaaaacaatataatcttgata & U74659 \\
\hline \multirow[t]{2}{*}{ P5 } & tctgctaatccatcttcatgaaaagcaccggttatgaggAgtgtagtaatcattgataggataatggcaagtg & \\
\hline & cagttgaaaaaaaaaaag & U74660 \\
\hline \multirow[t]{2}{*}{ P6 } & ggcgcgttgctttggcgagatgaacggctttgggaagctgcgntctcttggtaaatacggcatcatctgcatg & \\
\hline & gaggatttgattcatgagatctatactgttggaaacgcttcaaagaggcaatgactctgtggcctcaa & U74661 \\
\hline \multirow[t]{2}{*}{$\mathrm{P} 7$} & ttgcgaacaatatagagtgctgaacgggtacattctacggggataatgatgttattattatcaatggttttat & \\
\hline & $\begin{array}{l}\text { acgcatcatcgtattttcaaaaaatcgatcctcttttttatcagatagataggcattaaatatatgtggtgcc } \\
\text { atatcccaaaactctct }\end{array}$ & U74662 \\
\hline \multirow[t]{2}{*}{ P8 } & cctgccactatagttatgtcatccetcttattaatcatcatcctagccctaagtctggcctatgagtgactac & \\
\hline & aaaaaggattagactgagccgaaaаaаaаaа & U74663 \\
\hline \multirow[t]{2}{*}{ P9 } & aaactgcgtttatstccacccacactatcatagattgsttaggtaaatacaatgcttatckagtggtattcta & \\
\hline & cttgkacacagmmtactgggtgaamatgtgt & U74664 \\
\hline \multirow[t]{2}{*}{ P10 } & ggaaactagtgacatgttttattggtatcacaactataggctcatcataaaacaanacaaagttgcaatattc & \\
\hline & tgcaggaaagaatcatttcttacgaaaataatttaat & U74665 \\
\hline \multirow[t]{2}{*}{ P11 } & tagaaaacaggggetgcttttaaactctcactatgggacactttaccaaaatacttccatatcaattatttga & \\
\hline & acccggtagtttgtttgacctagttagattgtggtgtttattcaag & U74666 \\
\hline
\end{tabular}

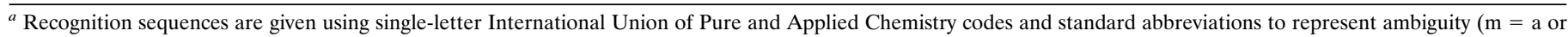
$\mathrm{c} ; \mathrm{k}=\mathrm{g}$ or $\mathrm{t}$ ).

Table 2. Identification of the ddPCR amplification products differentially displayed in $\mathrm{E}_{\mathbf{2}}$-treated $\mathrm{SK}$-ER3 cells versus nontreated cells

\begin{tabular}{|c|c|c|c|c|c|c|}
\hline \multirow[b]{2}{*}{ Product } & \multirow{2}{*}{$\begin{array}{l}\text { ddPCR } \\
\text { primers }\end{array}$} & \multicolumn{3}{|c|}{ Amplification extent } & \multirow[b]{2}{*}{ Homology search } & \multirow{2}{*}{$\begin{array}{l}\text { Accession } \\
\text { number }\end{array}$} \\
\hline & & $\mathrm{C}$ & $\mathrm{E}_{2} 1 \mathrm{hr}$ & $\mathrm{E}_{2} 17 \mathrm{hr}$ & & \\
\hline $\mathrm{P} 1$ & $\mathrm{dT}_{11} \mathrm{~A} / \mathrm{AP}-3$ & + & ++ & +++ & Mitochondrial DNA & D38112 \\
\hline $\mathrm{P} 2$ & $\mathrm{dT}_{11} \mathrm{~A} / \mathrm{AP}-5$ & ++ & +++ & +++ & No match & \\
\hline P3 & $\mathrm{dT}_{11} \mathrm{~A} / \mathrm{AP}-7$ & + & ++ & +++ & Prothymosin- $\alpha$ & M14630 \\
\hline P4 & $\mathrm{dT}_{11} \mathrm{~A} / \mathrm{AP}-7$ & +++ & ++ & + & No match & \\
\hline P5 & $\mathrm{dT}_{11} \mathrm{C} / \mathrm{AP}-6$ & ++ & - & - & No match & \\
\hline P6 & $\mathrm{dT}_{11} \mathrm{C} / \mathrm{AP}-7$ & +++ & ++ & + & Fetal brain & D53265 \\
\hline P7 & $\mathrm{dT}_{11} \mathrm{C} / \mathrm{AP}-8$ & ++ & + & ++ & No match & \\
\hline P8 & $\mathrm{dT}_{11} \mathrm{C} / \mathrm{AP}-8$ & + & ++ & +++ & Mitochondrial DNA & D38112 \\
\hline P9 & $\mathrm{dT}_{11} \mathrm{G} / \mathrm{AP}-3$ & ++ & - & - & No match & \\
\hline P10 & $\mathrm{dT}_{11} \mathrm{G} / \mathrm{AP}-12$ & ++ & +++ & + & Homo sapiens cDNA & Z39668 \\
\hline P11 & $\mathrm{dT}_{11} \mathrm{G} / \mathrm{AP}-12$ & +++ & + & ++ & Nip2 & U15173 \\
\hline
\end{tabular}

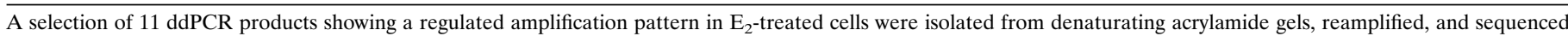

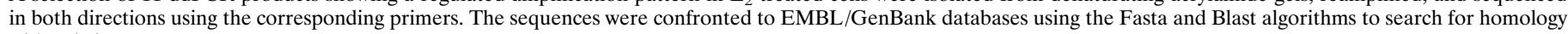
with existing sequences.

to any known message. On the contrary, a high degree of homology (90-100\%) was found between the ddPCR products P1, P3, P6, P8, P10, and P11 and previously reported sequences encoding for proteins associated with growth and cell death, uncharacterized fetal proteins, and mitochondrial enzymes (Table 2).

Among these, the P3 amplification product seemed to be upregulated by $E_{2}$ after 1 and $17 \mathrm{hr}$ treatment and showed $100 \%$ identity with a 207 bp sequence of PTMA, a nuclear protein that has been associated with proliferation and/or differentiation in other eukaryotic cell models (Eschenfeldt and Berger, 1986; Bustelo et al., 1991). The P3 product was located within the open reading frame of PTMA containing at least 69 amino acids (aa) of the C-terminal region of the protein. In contrast, a 410 bp ddPCR product (P11) amplified by the primer combination $\mathrm{H}-\mathrm{dT}_{11} \mathrm{G} / \mathrm{H}$ AP12 seemed to be downregulated by $E_{2}$ treatment. Sequence analysis revealed $100 \%$ homology with the $3^{\prime}$-end untranslated region of Nip2, a protein recently described to associate with the Bcl2 proto-oncogene. The identity of $\mathrm{P} 11$ and the presence of Nip2 in SK-ER3 cells were further confirmed using two specific primers contained in the Nip2 coding sequence and P11 (data not shown). A similar downregulation pattern was observed in $E_{2}$ treated cells for the $\mathrm{P} 6$ product generated by the $\mathrm{H}-\mathrm{dT}_{11} \mathrm{C} / \mathrm{H}-\mathrm{AP} 7$ primer set. A 141 bp sequence was characterized in the P6 product and showed $100 \%$ homology with a partial DNA previously iso- 
fragment \# 3 (prothymosin $\alpha$ )

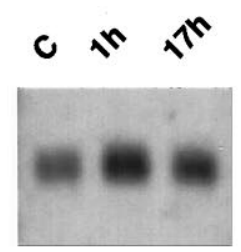

$28 \mathrm{~S}$ $18 \mathrm{~S}$
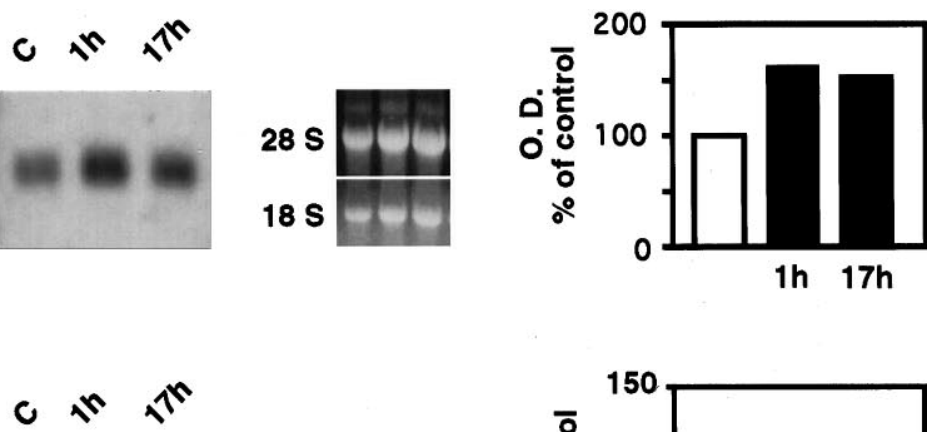

fragment \# 4
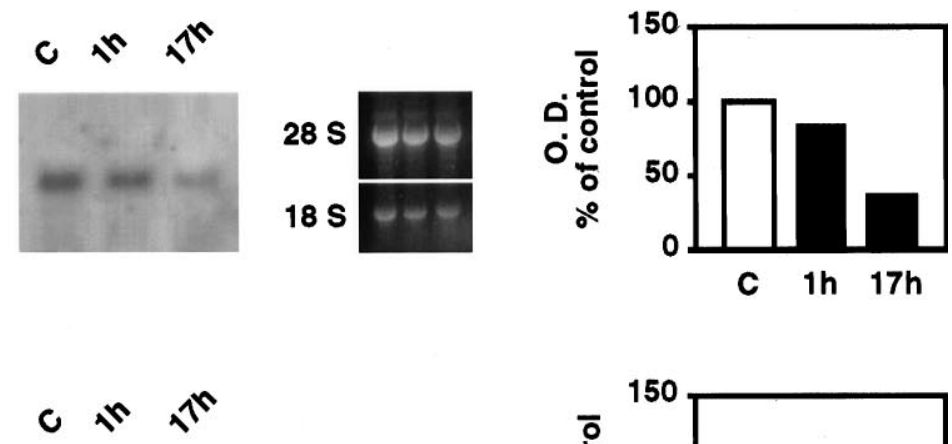

fragment \# 6

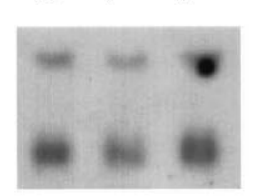

$28 \mathrm{~S}$

$18 \mathrm{~S}$
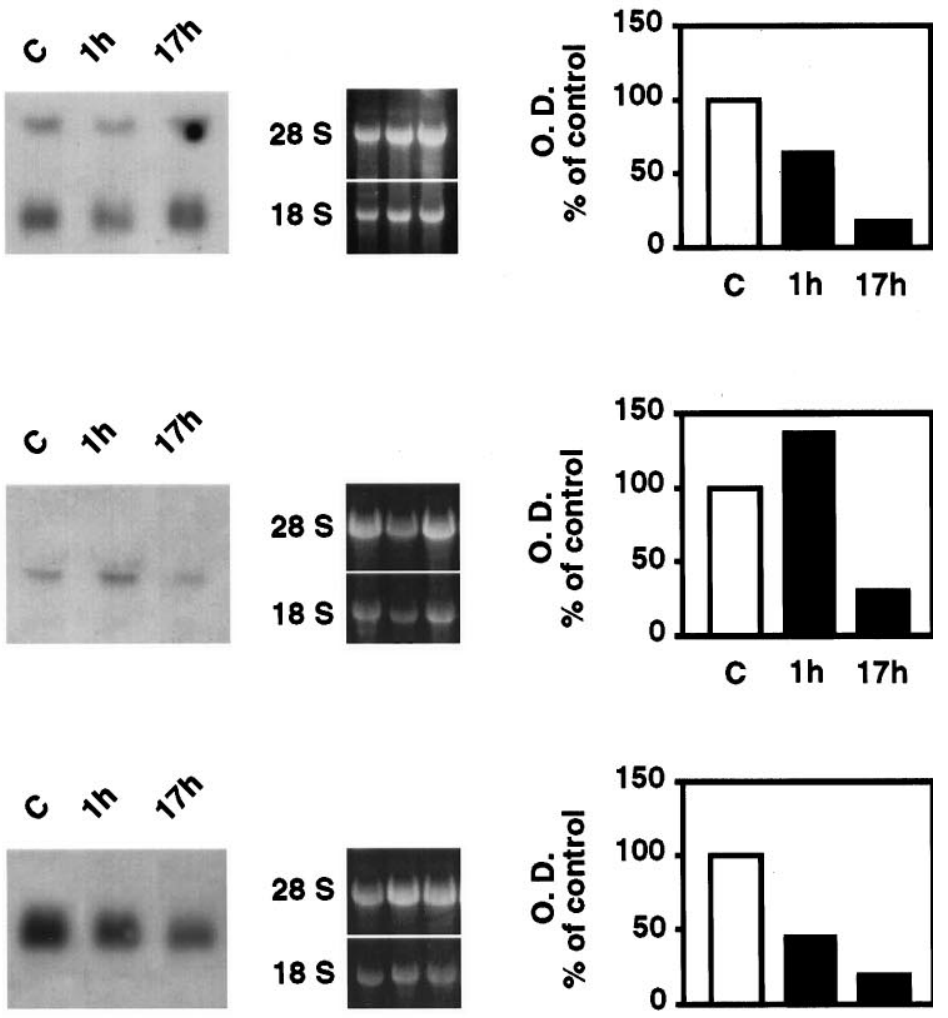

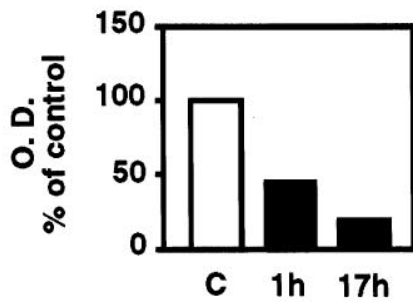

Figure 2. Northern analysis of the expression of SK-ER3 messages identified by differential display PCR. Northern blot analyses were performed using digoxigenin-labeled ddPCR products as hybridization probes. Gels were loaded with $10 \mu \mathrm{g}$ of total RNA from either control $(C)$ or cells treated with $\mathrm{E}_{2}$ for 1 or $17 \mathrm{hr}(1 \mathrm{~h}$ and $17 \mathrm{~h})$. Left panels, Autoradiographs from Northern analysis. Center panels, Ethidium bromidestained 18 and $28 \mathrm{~S}$ rRNAs. Right panels, The relative band intensities were estimated by densitometric analysis of autoradiographs after normalization with respect to 18 and 28 S RNAs. Bars represent the averages of two to five separate determinations. O.D., Optical density.

lated from human fetal brain. The identity of P6 DNA was further confirmed using primers specific to the reported brain DNA (data not shown). Finally, two ddPCR amplification products (P1 and P8) were $100 \%$ homologous to nucleotides (nt) 1636-1714 and nt 9731-9817 of the $16 \mathrm{~kb}$ mitochondrial DNA isolated from human placenta. These regions are contained in the sequences coding for the $16 \mathrm{~S}$ ribosomal RNA (rRNA) and NADH dehydrogenase subunit 3 in eukaryotic cells. Both messages seemed upregulated by $E_{2}$ after 1 and $17 \mathrm{hr}$ of treatment.

\section{Northern blot analysis of differentially amplified ddPCR products}

The hormonal regulation of the transcripts corresponding to five of the ddPCR products was further studied by Northern analysis.

Nonradioactive probes were generated by labeling the purified ddPCR products with DIG and were hybridized to RNAs from control or $E_{2}$-treated cells, blotted on nylon membranes. The hybridization bands were quantitated by densitometric scanning of the autoradiographs, followed by normalization with respect to 28 and $18 \mathrm{~S}$ rRNAs stained with ethidium bromide (Fig. 2). The $\mathrm{E}_{2}$-regulation profiles of PTMA, P4, the fetal brain, P10, and Nip2 DNAs were all confirmed by Northern analysis.

The $\mathrm{P} 3$ probe hybridized to a major transcript of about $1.4 \mathrm{~kb}$, which corresponds to the reported size for PTMA mRNA (Goodall et al., 1986). The full-length PTMA coding sequence was obtained in SK-ER3 cells by using specific primers and was shown to be identical to the previously reported human $\mathrm{T}$ lymphocyte 
PTMA (Gomez-Marquez et al., 1989). Northern analysis confirmed that the levels of PTMA transcript were significantly increased after a $1 \mathrm{hr}$ treatment with $\mathrm{E}_{2}$ and remained above basal level for at least $17 \mathrm{hr}$.

$\mathrm{P} 4$ corresponded to a transcript of about $1.5 \mathrm{~kb}$, which seemed to be downregulated by $\mathrm{E}_{2}$ treatment during the first $17 \mathrm{hr}$.

Northern analysis of the fetal brain DNA (P6) revealed two bands corresponding to a major transcript of approximatively 0.8 $\mathrm{kb}$ and an additional one of about $1.5 \mathrm{~kb}$, which were equally decreased by the treatment.

The P10 probe revealed a band of about $1.4 \mathrm{~kb}$ and confirmed that $E_{2}$ induced a slight upregulation of P10 mRNA at $1 \mathrm{hr}$ of treatment, followed by a significant downregulation at $17 \mathrm{~h}$.

Nip2 message was of about $1.7 \mathrm{~kb}$, and its content was significantly decreased by $\mathrm{E}_{2}$ at 1 and $17 \mathrm{hr}$.

Differences in the content of six products, which seemed to be differentially amplified in the ddPCR profiles, failed to be reconfirmed by Northern analysis, partly because the specific activity of the DIG probes was too weak to allow signal detection with the nonradioactive method used, partly because they represented false-positive results inherent in the ddPCR method.

\section{Nip2 and prothymosin- $\alpha$ regulation of expression in SK-ER3 cells}

The effects of $E_{2}$ on neural growth and differentiation are likely to involve the regulation of expression of various proteins acting in a coordinated manner to control the proliferation, phenotype expression, and, possibly, cell survival. The growth and differentiating effects of $E_{2}$ on SK-ER3 cells and our recent observation that these cells, once differentiated, arrest in the $G_{0}$ phase of the cell cycle (Agrati et al., 1997) prompted us to focus further on PTMA and Nip2 regulation of expression. In effect, several reports have associated PTMA with cell growth and differentiation processes (Eschenfeldt and Berger, 1986). On the other hand, Nip2 might be involved in mechanisms of cell death protection (Boyd et al., 1994; White, 1996). Because SK-ER3 cells can be induced to differentiate after a short exposure to the hormone ( $4 \mathrm{hr})$, whereas the induction of proliferation blockade requires at least $16 \mathrm{hr}$ of hormonal treatment (Ma et al., 1993), the effect of $E_{2}$ was studied in two types of experiments. At first, estradiol was kept in the culture medium for the total duration of the experiment. At various periods, cells were harvested and assessed for Nip2 and PTMA mRNA cell content by Northern analysis. As shown in Figures 3 and 4, Nip2 and PTMA mRNAs were constitutively expressed in proliferating control SK-ER3 cells. Interestingly, we observed that the downregulatory effect of $E_{2}$ on Nip2 mRNA was transient, the levels of Nip2 mRNA reaching control values after $4 \mathrm{~d}$ of exposure to the hormone (Fig. 3). Similarly, $\mathrm{E}_{2}$ demonstrated a biphasic effect on the levels of PTMA mRNA. As presented above, PTMA mRNA accumulated during the first 17 $\mathrm{hr}$ of treatment. Thereafter and over the following $5 \mathrm{~d}$, the message levels decreased steadily. At the sixth $d$, the amount of PTMA mRNA in $\mathrm{E}_{2}$-treated SK-ER3 cells accounted for $<20 \%$ of the control (Fig. 4).

In a second series of experiments, we investigated whether the upregulations and downregulations of PTMA and Nip2 mRNAs required the continuous presence of $E_{2}$. In this respect, the time course study was repeated in the same way, except that the cells were only treated with $\mathrm{E}_{2}$ for the first $4 \mathrm{hr}$; the cultures were then thoroughly washed with estrogen-deprived normal medium to eliminate the presence of the hormone, and the cells were further grown for $17 \mathrm{hr}$ and 2, 4, and $6 \mathrm{~d}$. Under such conditions, PTMA

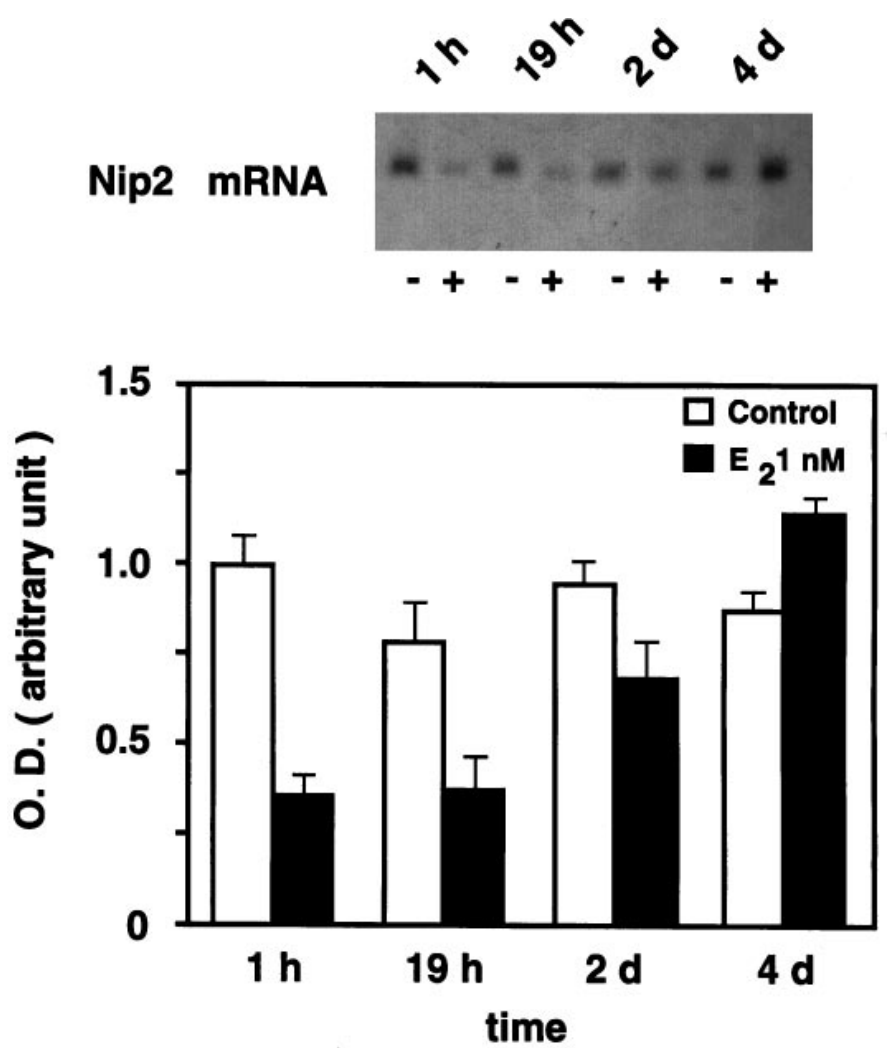

Figure 3. Time course of the effect of $\mathrm{E}_{2}$ on Nip2 expression in SK-ER3 neuroblastoma cells. Cells were plated in six-well dishes and then grown in the absence or presence of $1 \mathrm{nM} \mathrm{E}_{2}$ described in Materials and Methods. Total RNAs were extracted at the indicated times and analyzed by Northern blot using a digoxigenin-labeled P6 ddPCR product as the hybridization probe. The relative band intensities (top, a representative experiment) were analyzed by densitometric analysis after normalization to ethidium bromide-stained 18 and $28 \mathrm{~S}$ rRNAs. Columns represent means \pm SEM (error bars) of six separate determinations. Statistical significance by two-way ANOVA with Tukey multiple range test: $p \leq 0.05$ versus control values $(1 h$ and $19 h) ; p \leq 0.01$ versus control values $(2 d$ and $4 d)$. O.D., Optical density.

and Nip2 mRNA levels exhibited the same biphasic regulation profile observed previously (data not shown). These data indicated that the biphasic regulation of PTMA and Nip2 expression required the activation of the estrogen receptor for its onset but could be carried out in the absence of the hormone.

\section{DISCUSSION}

The identification of genes that are modulated by $E_{2}$ in cells of neural origin is an important step to understand the effects of the hormone on brain functions better and eventually to develop new therapeutics for estrogen-sensitive disorders. In the present study, we focused on the identification of messages regulated by $E_{2}$ in SK-ER3 neuroblastoma cells using the ddPCR approach. This method proved quite reproducible and allowed us to identify a group of early genes in the cascade of events triggered by the hormone. Among the DNAs presently reported, six corresponded to sequences identified for the first time, whereas five showed 80-100\% homology with previously reported sequences.

The ddPCR method applied here makes use of $1 \mathrm{~b}$ anchor poly-dT primers combined with arbitrary primers in the RTddPCR reactions (Liang and Pardee, 1992). Although annealing of the primers can occur in any region of the mRNAs complementary to the primer sequence, the use of an anchor oligo-dT 


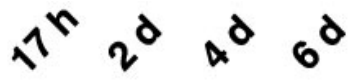

prothymosin $\alpha$ mRNA
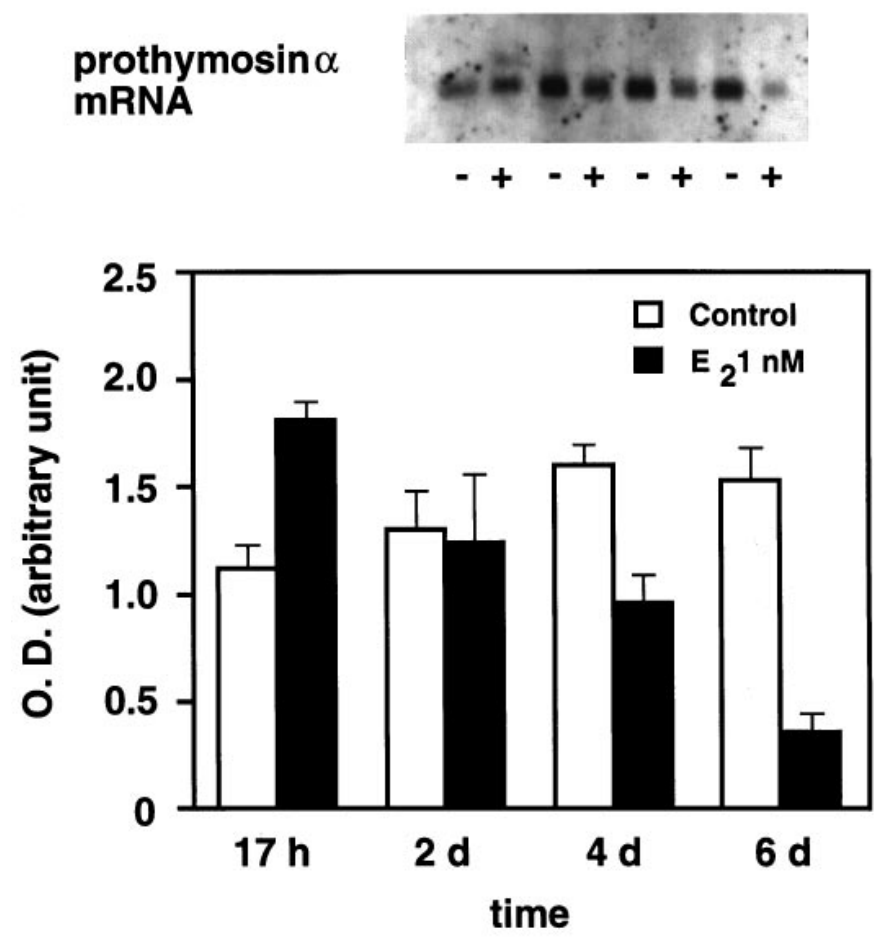

Figure 4. Time course of the effect of $\mathrm{E}_{2}$ on PTMA expression in SK-ER3 neuroblastoma cells. Cells were plated in six-well dishes and then grown in the absence or presence of $1 \mathrm{nM} \mathrm{E}_{2}$ as described in Materials and Methods. Total RNAs were extracted at the indicated times and analyzed by Northern blot using a digoxigenin-labeled P3 ddPCR product as the hybridization probe. The relative band intensities (top, a representative experiment) were analyzed by densitometric analysis after normalization to ethidium bromide-stained 18 and $28 \mathrm{~S}$ rRNAs. Columns represent the means \pm SEM (error bars) of six separate determinations. Statistical significance by two-way ANOVA with Tukey multiple range test: $p \leq 0.05$ versus control values $(17 h) ; p \leq 0.01$ versus control values ( $4 d$ and $6 d$ ). O.D., Optical density.

primer likely favors the amplifications of the $3^{\prime}$-ends of the message. This represents a minor drawback for the identification of the sequences isolated, because these regions are the least conserved. This may explain that we did not find any significant homology for P2, P4, P5, P7, P9, and P10 ddPCR products. The complete characterization of the corresponding coding sequences will be necessary to allow their identification.

Northern analysis confirmed that five of the messages identified by ddPCR were regulated in response to estrogens. In particular, we found that two of these code for the known proteins Nip2 and PTMA, previously associated with cell death protection and cell growth and differentiation.

PTMA, an acidic nuclear protein of $12.5 \mathrm{kDa}$ (Haritos et al., 1984a; Gomez-Marquez and Segrade, 1988; Watts et al., 1989) originally isolated from the thymus, was believed to regulate immunological processes. Further studies demonstrated that PTMA is present in a large variety of cell types, tissues, and organisms (Haritos et al., 1984b; Eschenfeldt and Berger, 1986; Clinton et al., 1989; Gomez-Marquez et al., 1989). The high degree of conservation of PTMA among species (Makarova et al., 1989) further suggests that it may be required for essential cell functions. Although its precise biological role has not been assigned yet, a number of in vivo (Dominguez et al., 1993) and in vitro studies (Gomez-Marquez et al., 1989; Bustelo et al., 1991; Sburlati et al., 1991) correlated PTMA with proliferative activities. The expression of PTMA was also found to be modulated during development in a number of tissues, including brain (Dosil et al., 1990).

Our findings suggest that PTMA is likely to participate in regulatory processes in cells of neural origin. We report here a biphasic regulation of PTMA mRNA over a 6-d period with a rapid increase as early as at $1 \mathrm{hr}$ of treatment with $\mathrm{E}_{2}$ followed by a significant decline at $17 \mathrm{hr}$. It is known that SK-ER3 cells, once treated with estrogens, keep proliferating for 2-3 d before acquiring a differentiated phenotype (Agrati et al., 1997). Previous reports demonstrated that the cellular content of PTMA mRNA increases with proliferation or in response to mitogens (GomezMarquez et al., 1989; Bustelo et al., 1991). Moreover, kinetic analysis showed that although PTMA mRNA is expressed throughout all phases of the cell cycle, it significantly increases in $\mathrm{G}_{1}$ after a mitogenic stimulation. This increase in PTMA seems to be required for the $G_{1}$ to $S$ transition (Szabo et al., 1992). Therefore, the increased content of PTMA observed in SK-ER3 cells at 1-17 hr after $E_{2}$ treatment could reflect an accelerated progression of the cells through the cell cycle induced by the hormone and could support the view that $\mathrm{E}_{2}$ might exert an initial mitogenic-like activity committing the cells to the differentiation pathways. The subsequent decrease of PTMA transcript level might indeed be related to the progression of the cells toward differentiation and their progressive accumulation in $G_{0}$. In effect, a decrease in PTMA levels has been previously associated with cell differentiation and possibly with the irreversible growth arrest usually taking place along the expression of the differentiated phenotype (Dosil et al., 1993).

To investigate whether PTMA is an $\mathrm{E}_{2}$-responsive gene, we performed a computer-assisted analysis of the 5 '-flanking sequence of the human PTMA gene and confirmed the presence of a number of potential binding sites for regulatory elements, including an E-box c-myc binding site (Szabo et al., 1993). No typical estrogen-responsive elements palindromic sequence (KleinHitpass et al., 1986) was found in the $2 \mathrm{~kb}$ promoter region. However, two direct half-palindromic repeats (TGACC) and one incomplete half-motif (GGTC) at positions -750, -1051, and -1437 , respectively were found. Previous reports have shown that such incomplete motifs might transduce ER signaling (Tora et al., 1988; Vegeto et al., 1996), leading us to the conclusion that the PTMA promoter may contain sequences conferring $\mathrm{E}_{2}$ responsiveness. Previous work showed that PTMA expression is regulated by MYC protein (Eilers et al., 1991). Because estrogen was shown to regulate myc expression, it could be hypothesized that the effect described here is dependent on MYC activity. In our cell model, estrogens do not regulate the expression of the nuclear proto-oncogene N-myc (Santagati et al., 1995), which represents the counterpart of c-myc in neural cells. Thus, in SK-ER3 cells the estrogen-dependent induction of PTMA cannot result from MYC activation.

The pattern of Nip2 regulation was opposite to that described for PTMA. In this study, the levels of Nip2 mRNA are rapidly decreased after $E_{2}$ treatment. This effect is transient and lasts for about $19 \mathrm{hr}$. Nip2 was recently described as one of the proteins interacting with the apoptosis inhibitors $\mathrm{Bcl} 2$ and E1B $19 \mathrm{kDa}$ proteins (White, 1996). Although little is known about the function of Nip2 within cells, mutational analysis indicated that the protein no longer associates with $\mathrm{Bcl} 2$ mutants defective in suppression of cell death, suggesting a role of Nip2 in apoptotic cell 
death (Boyd et al., 1994). The mechanism by which Bcl2 or its homologues promote cell survival is not known. One of the current hypotheses proposes that apoptosis may result from the proteolytic cleavage of one or several critical substrates and that antiapoptotic agents may either block the activation of specific proteases or protect their proteolityc substrates (Cory et al., 1994). A computer-based search of homology was performed between Nip2 and members of the interleukin- $1 \beta$-converting enzyme (ICE)/Ced-3 protease family (Thornberry et al., 1992; Duan et al., 1996; Schwartz and Milligan, 1996; Wang et al., 1996) using the LFASTA algorithm and the BLOSUM50 matrix file. Interestingly, Nip2 showed a significant homology $(19.7 \%$ overall identity on 303 aa overlap and up to $80 \%$ identity on distinct block regions) with the human ICE protease, a member of a highly conserved multigene family of cysteine proteases involved in apoptosis (Thornberry et al., 1992). Moreover, the tripeptide SHG sequence, which was shown to participate in the catalytic activity of these proteases, was conserved in Nip2 (Schwartz and Milligan, 1996). The homology between Nip2 and ICE protease led us to speculate that the decreased levels of Nip2 observed in SK-ER3 cells at a short time after estrogen treatment might protect these cells from death. This may be correlated with the known protective effect of $E_{2}$ on survival previously described in SK-ER3 cells (Di Lorenzo et al., 1996) and hypothesized in specific neurodegerative disorders (Tang et al., 1996). Moreover, preliminary studies show that Nip2 is expressed in rat adult brain, and $E_{2}$ treatment causes a decrease in its mRNA levels, suggesting that estrogen effect may occur in vivo and may not be limited to developmental processes.

With regard to the other mRNAs hereby described as modulated by estrogens, we found of interest the fact that two mitochondrial DNAs were increased after $E_{2}$ treatment. Although we failed in generating suitable probes for Northern analysis, this observation is consistent with: (1) previous studies in neural tissues (Bettini and Maggi, 1992) and in non-neural cells (Van Itallie and Dannies, 1988), which described an effect of $E_{2}$ on the expression of another mitochondrial gene, namely cytochrome $c$-oxidase subunit III; and (2) the well described increase in neuronal activity (i.e., increased firing) induced by estrogens.

Finally, the identification of a message present in fetal brain (P6 product) led us to speculate on our cell model. The particular neuroblastoma cells used to generate the SK-ER3 cell line are derived from a tumor of neural crest cells at a very early stage of differentiation (Ciccarone et al., 1989). Considering that neural crest derivatives express the estrogen receptor (Sohrabji et al., 1994), it is conceivable that the genes we found in SK-ER3 cells may also be modulated by the hormone in immature cells expressing the estrogen receptor and may constitute part of the genomic pool leading to the maturation of the neural cells.

Further studies will prove whether the messages described here represent estrogen targets in both immature and mature neural cells, and whether their expression is also altered in estrogensensitive neurological disorders. In this respect, the finding that estrogens regulate the expression of genes related to cell growth and survival, such as PTMA and Nip2, might be of relevance with regard to the known protective effects of estrogens in the manifestation of neurodegenerative disorders such as Alzheimer's disease (Tang et al., 1996).

The present study provides new insights into the molecular mechanism of action of estrogens in neural cells and points to new strategies to investigate the estrogen actions in neural cells further.

\section{REFERENCES}

Agrati P, Ma ZQ, Patrone C, Picotti GB, Pellicciarci C, Bondiotti G, Bottone MG, Maggi A (1997) Dopaminergic phenotype induced by estrogens in a human neuroblastoma cell line. Eur J Neurosci, in press.

Altschul SF, Gisg W, Miller W, Myers EW, Lipman DJ (1990) Basic local alignment search tool. J Mol Biol 215:403-410.

Bettini E, Maggi A (1992) Estrogen induction of cytochrome $c$ oxydase subunit III in rat hippocampus. J Neurochem 58:1923-1929.

Boyd JM, Malstrom S, Subramanian T, Venkatesch LK, Schaeoer U, Elangovan B, D'Sa-Eipper C, Chinnadurai G (1994) Adenovirus E1B $19 \mathrm{kDa}$ and $\mathrm{Bcl}-2$ proteins interact with a common set of cellular proteins. Cell 79:341-351.

Bustelo XR, Otero A, Gomez-Marquez J, Freire M (1991) Expression of rat prothymosin $\alpha$ gene during T-lymphocyte proliferation and liver regeneration. J Biol Chem 266:1443-1447.

Chomczynski P, Sacchi N (1987) Single-step method of RNA isolation by acid guanidinium thiocyanate-phenol-chloroform extraction. Anal Biochem 162:156-159.

Ciccarone V, Spengler BA, Meyers MB, Biedler JL, Ross RA (1989) Phenotypic diversification in human neuroblastoma cells: expression of distinct neural crest lineages. Cancer Res 49:219-225.

Clinton M, Frangou-Lazaridis M, Panneerselvam C, Horecker BL (1989) Prothymosin $\alpha$ and parathymosin: mRNA and polypeptide levels in rodent tissues. Arch Biochem Biophys 269:256-263.

Cory S, Strasser A, Jacks T, Corcoran LM, Metz T, Harris AW, Adams JM (1994) Enhanced cell survival and tumorigenesis. Cold Spring Harbor Symp Quant Biol 59:365-375.

Di Lorenzo D, Ferrari F, Agrati P, De Vos H, Apostoli P, Alessio L, Albertini A, Maggi A (1996) Manganese effects on the human cell line SK-ER3. Toxicol Appl Pharmacol 140:51-57.

Dominguez F, Magdalena C, Cancio E, Roson E, Paredes J, Loidi L, Zalvide J, Fraga M, Forteza J, Regueiro BJ (1993) Tissue concentration of prothymosin $\alpha$ : a novel proliferative index of primary breast cancer. Eur J Cancer 29(A)6:893-897.

Dosil M, Freire M, Gomez-Marquez J (1990) Tissue-specific and differential expression of prothymosin alpha gene during rat development. FEBS Lett 269:273-276.

Dosil M, Alvarez FL, Gomez MJ (1993) Differentiation-linked expression of prothymosin alpha gene in human myeloid leukemia cells. Exp Cell Res 204:94-101.

Douglass J, McKinzie AA, Couceyro P (1995) PCR differential display identifies a rat brain mRNA that is transcriptionally regulated by cocaine and amphetamine. J Neurosci 15:2471-2481.

Duan H, Orth K, Chinnaiyan AM, Poirier GG, Froelich CJ, He WW, Dixit VM (1996) ICE-LAP6, a novel member of the ICE/Ced-3 gene family, is activated by the cytotoxic $\mathrm{T}$ cell protease granzyme $\mathrm{B}$. J Biol Chem 271:16720-16724.

Eilers M, Schirm S, Bishop JM (1991) The MYC protein activates transcription of the $\alpha$-prothymosin gene. EMBO J 10:133-141.

Eschenfeldt WH, Berger SL (1986) The human prothymosin $\alpha$ gene is polymorphic and induced upon growth stimulation: evidence using a cloned cDNA. Proc Natl Acad Sci USA 83:9403-9407.

Evans RM (1988) The steroid and thyroid hormone receptor superfamily. Science 240:889-896.

Gomez-Marquez J, Segrade F (1988) Prothymosin $\alpha$ is a nuclear protein. FEBS Lett 226:217-219.

Gomez-Marquez J, Segade F, Dosil M, Pichel JG, Bustelo XR, Freire M (1989) The expression of prothymosin $\alpha$ gene in T lymphocytes and leukemic lymphoid cells is tied to lymphocyte proliferation. J Biol Chem 264:8451-8454.

Goodall GJ, Dominguez F, Horecker BL (1986) Molecular cloning of cDNA for human prothymosin $\alpha$. Proc Natl Acad Sci USA 83:8926-8928.

Haritos AA, Goodall GJ, Horecker BL (1984a) Prothymosin: isolation and properties of the major immunoreactive form of thymosin $\alpha 1$ in rat thymus. Proc Natl Acad Sci USA 81:1008-1011.

Haritos AA, Tsolas O, Horecker BL (1984b) Distribution of prothymosin in rat tissues. Proc Natl Acad Sci USA 81:1391-1393.

Innis MA, Myambo KB, Gelfand DH, Brown MAD (1988) DNA sequencing with Thermus aquaticus DNA polymerase and direct sequencing of polymerase chain reaction-amplified DNA. Proc Natl Acad Sci, USA 85:9436-9440.

Klein-Hitpass L, Schorpp M, Wagner U, Ryffel U (1986) An estrogenresponsive element derived from the $5^{\prime}$ flanking region of Xenopus 
vitellogenin A2 gene functions in transfected human cells. Cell 46:1053-1061.

Klein-Hitpass L, Tsai SY, Greene GL, Clark JH, Tsai M, O’Malley BW (1989) Specific binding of estrogen receptor to the estrogen responsive element. Mol Cell Biol 9:43-49.

Kumar V, Chambon P (1988) The estrogen receptor binds to its responsive element as a ligand-induced homodimer. Cell 55:145-156.

Liang P, Pardee AB (1992) Differential display of eukariotic messenger RNA by means of the polymerase chain reaction. Science 257:967-971.

Luine VN (1994) Steroid hormone influences on the spatial memory. Ann NY Acad Sci 14:201-211.

Ma ZQ, Speafico E, Pollio G, Santagati S, Conti E, Cattaneo E, Maggi A (1993) Activated estrogen receptor mediates growth arrest and differentiation of a neuroblastoma cell line. Proc Natl Acad Sci USA 90:3740-3744.

MacLusky NJ, Naftolin F (1981) Sexual differentiation of the central nervous system. Science 211:1294-1303.

Maggi A, Perez J (1985) Role of the female gonodal hormones in the CNS: clinical and experimental aspects. Life Sci 37:863-907.

Maggi A, Susanna L, Bettini E, Mantero G, Zucchi I (1989) Hippocampus: a target for estrogen action in mammalian brain. Mol Endocrinol 3:1165-1170.

Makarova T, Grebenshikov N, Egorov C, Vartapetian A, Bogdanov A (1989) Prothymosin is an evolutionary conserved protein covalently linked to a small RNA. FEBS Lett 257:247-250.

McEwen BS (1983) Gonadal steroid influences on brain development and sexual differentiation. Int Rev Physiol 27:99-145

McEwen BS, Davis PG, Parsons B, Pfaff DW (1979) The brain as a target for steroid hormone action. Annu Rev Neurosci 2:65-112.

Pahlman S, Mamaeva S, Meyerson G, Mattsson MEK, Bjelfman C, Ortoft E, Hammerling U (1990) Human neuroblastoma cells in culture: a model for neuronal cell differentiation and function. Acta Physiol Scand Suppl 592:25-37.

Parsons B, MacLusky NJ, Krey L, Pfaff DW, McEwen BS (1980) The temporal relationship between estrogen-inducible progestin receptors in the female rat brain and the time course of estrogen activation of mating behavior. Endocrinology 107:774-779.

Sambrook J, Fritsch EF, Maniatis T (1989) Molecular cloning: a laboratory manual, Ed 2. Plainview, NY: Cold Spring Harbor.

Santagati S, Ma ZQ, Ferrarini C, Pollio G, Maggi A (1995) Expression of early genes in estrogen induced phenotypic conversion of neuroblastoma cells. J Neuroendocrinol 7:875-879.

Sburlati NR, Manrow RE, Krug MS, Berger SL (1991) Prothymosin antisense oligomers inhibit myeloma cell division. Proc Natl Acad Sci USA 88:253-257.

Schwartz LM, Milligan CE (1996) Cold thoughts of death: the role of ICE proteases in neuronal cell death. Trends Neurosci 19:555-562.

Sherwin RB (1994) Estrogenic effects on memory in women. In: Hormonal restructuring of the adult brain (Luine VN, Harding CF, eds), pp 213-218. New York: New York Academy of Sciences.

Shughrue PJ, Dorsa DM (1993) Estrogen modulates the growth- associated protein GAP-43 (neuromodulin) mRNA in the rat preoptic area and basal hypothalamus. Neuroendocrinology 57:439-447.

Sohrabji F, Miranda RS, Toran-Allerand D (1994) Estrogen differentially regulates estrogen and nerve growth factor receptor mRNA in adult sensory neurons. J Neurosci 14:459-471.

Summer BEH, Fink G (1993) Effects of acute estradiol on 5hydroxytryptamine and dopamine receptor subtype mRNA expression in female rat brain. Mol Cell Neurosci 4:83-92.

Szabo P, Panneerselvam C, Clinton M, Frangou-Lazaridis M, Weksler D, Whittington E, Hacera MJ, Grzeschik KH, Selvakumar A, Horecker BL (1993) Prothymosin $\alpha$ gene in humans: organization of its promoter region and localization to chromosome 2. Hum Genet 90:629-634.

Tallal P (1991) Hormonal influences in developmental learning disabilities. Psychoneuroendocrinology 16:203-212.

Tang MX, Jacobs D, Stern Y, Marder K, Schofield P, Gurland B, Andrews H, Mayeux R (1996) Effect of estrogens during menopause on risk and age at onset of Alzheimer's disease. Lancet 348:429-433.

Thornberry NA, Bull HG, Calaycay JR, Chapman KT, Howard AD, Kostura MJ, Miller DK, Molineaux SM, Weidner JR, Aunins J (1992) A novel heterodimeric cysteine protease is required for interleukin-1 beta processing in monocytes. Nature 356:768-774.

Tora L, Gaub MP, Mader S, Dierich A, Bellard M, Chambon P (1988) Cell-specific activity of a GGTCA half-palindromic estrogen-responsive element in the chicken ovalbumin gene promoter. EMBO J 7:3771-3778.

Toran-Allerand CD (1984) On the genesis of the sexual differentiation of the central nervous system: morphogenetic consequences of steroidal exposure and the possible role of $\alpha$-fetoprotein. Prog Brain Res 61:63-96.

Toran-Allerand CD (1996) Mechanisms of estrogen action during neural development: mediation by interactions with the neurotrophins and their receptors. J Steroid Biochem 56:169-178.

Toran-Allerand CD, Miranda RC, Hochberg RB, MacLusky NJ (1992) Cellular variations in estrogen receptor mRNA translation in the developing brain: evidence from combined $\left[{ }^{125} \mathrm{I}\right]$ estrogen autoradiography and non-isotopic in situ hybridization hystochemistry. Brain Res 576:25-41.

Van Itallie TJ, Dannies P (1988) Estrogen induces accumulation of the mitochondrial ribonucleic acid for subunit II of cytochrome oxidase in pituitary tumor cells. Mol Endocrinol 2:332-337.

Vegeto E, Wagner BL, Imhof MO, McDonnell DP (1996) The molecular pharmacology of ovarian steroid receptors. In: Vitamins and hormones, Vol 52 (Litwack G, ed), pp 99-128. San Diego: Academic.

Wang S, Miura M, Jung YK, Zhu H, Gagliardini V, Shi L, Greenberg AH, Yuan J (1996) Identification and characterization of Ich-3, a member of the interleukin- $1 \beta$ converting enzyme (ICE)/Ced-3 family and an upstream regulator of ICE. J Biol Chem 271:20580-20587.

Watts JD, Cory PD, Crane-Robinson C (1989) Prothymosin $\alpha$ is a nuclear protein. FEBS Lett 245:17-20.

White E (1996) Life, death, and the pursuit of apoptosis. Genes Dev 10:1-15. 